\title{
Spatial distribution in a temperate coastal ecosystem of the wild stock of the farmed oyster Crassostrea gigas (Thunberg)
}

\author{
Bruno Cognie $e^{\underline{a}}$, Joël Haure ${ }^{\underline{b}}$ and Laurent Barillé ${ }^{\underline{a}}$
}

\author{
aUniversité de Nantes, Laboratoire de Biologie Marine, UPRES EA 2663, Faculté des Sciences et des \\ Techniques, 2 rue de la Houssinière, Nantes, F-44322, France \\ ${ }^{\mathrm{b}}$ IFREMER, Laboratoire Conchylicole des Pays de Loire, Polder des Champs, Bouin, F-85230, France \\ Corresponding author : Bruno.Cognie@univ-nantes.fr
}

\begin{abstract}
:
The Pacific oyster, Crassostrea gigas, well known throughout the world because of its ability to adapt to a wide range of environmental conditions, was introduced for cultivation into France on a massive scale in the 1970s. With global warming, the reproductive population, confined at the beginning to the south of the French Atlantic coast, became established at more northern latitudes (above $45^{\circ} 58^{\prime} \mathrm{N}$ ), and wild $\mathrm{C}$. gigas began to colonize coastal areas such as our study site, Bourgneuf Bay $\left(1^{\circ}-2^{\circ} \mathrm{W}\right.$, $46^{\circ}-47^{\circ} \mathrm{N}$ ), an oyster-farming site. An original approach, based on orthophotograph analysis and in situ biomass sampling, revealed that, in the northern part of this bay, more than $70 \%$ of the total $\mathrm{C}$. gigas biomass was composed of wild oysters (i.e. C. gigas not bred by oystermen). The analysis of the spatial distribution of wild oysters indicated that $75 \%$ of the stock consisted of wild oysters in natural beds (rocky areas) and on low retaining walls of former fisheries. Wild C. gigas also colonized oysterfarming structures with lower biomasses ( $21 \%$ of the stock composed of wild oysters), but locally they could reach densities of up to $55 \mathrm{~kg} . \mathrm{m}-1$ i.e. 2.5 times the mean biomass of cultivated oysters. The economic and ecological consequences of this colonization by $\mathrm{C}$. gigas of an oyster culture site are discussed. Wild oyster seems to be the principal trophic competitor of cultivated oysters in Bourgneuf Bay. This may partly explain the decrease in growth of cultivated oysters observed in this bay during the last decade. Moreover, the trophic and spatial competition exerted by wild oysters may also affect the native biota and, in particular, the honeycomb worm Sabellaria alveolata.
\end{abstract}

The results obtained in this study have led oyster farmers and regional authorities to modify oysterfarming practices and to destroy wild oyster stocks in concession areas.

Résumé

Keywords: Crassostrea gigas; Introduced species; Wild stock; Invasion; Orthophotographs 


\section{Introduction}

In the history of man, coastal environments have been extensively invaded by exotic (non-indigenous) species. Different sources of these dispersals have been described: (1) fouling and boring communities on ships; (2) spores, larvae or resting stages in ballast seawater from ships; (3) inadvertent or (4) intentional fisheries introductions (mariculture and marina agronomy) (Carlton, 1987; Carlton and Geller, 1993; Naylor et al., 2001). For mollusks, especially bivalves, deliberate introductions have been prominent. Since the turn of the last century, bivalve mollusk shellfish have been transplanted to new countries to maintain or increase an existing activity or to develop a new industry. Thus, the Pacific oyster (Crassostrea gigas) originating from Japan, was introduced into Europe in the 1970's following the drastic mortality of the Portuguese oyster (Crassostrea angulata) in the 1960's (Grizel, 1996). However, C. gigas is, like all members of the genus, subtropical. Its temperature requirements for spawning [above $18{ }^{\circ} \mathrm{C}$ (Mann, 1979)] and larval development [above $22^{\circ} \mathrm{C}$ (Seno et al., 1926; Arakawa, 1990; Shatkin et al., 1997)] explain that recruitment in Europe was irregular at first (Le Borgne et al., 1973) depending on summer climatic conditions. This poor recruitment was compensated by massive implantations of adult oysters and spat, which led to the settling of natural productive stocks in the bay of Marennes-Oléron and in the bay of Arcachon (Grizel, 1996). Since 1976, the spat production of these bays has been adequate to supply northern areas (above $45^{\circ} 58^{\prime} \mathrm{N}$ ) where temperatures did not allow sufficient $C$. gigas spawning and larval development for its cultivation. However, wild populations became established in many areas where $C$. gigas was introduced for culturing but where offspring were not expected [e.g. Australia (Ayres, 1991), the British Isles (Hayward and Ryland, 1995), and the Netherlands (Kluijver and Leewis, 1994; Reise, 1998)]. In fact, with the rise in temperature during the last decade, environmental conditions in these areas have probably become favorable for natural recruitment and dispersal of the cupped oyster. Consequently, in these areas of introduction for cultivation, C. gigas has become a permanent member of the biotic community.

Bourgneuf Bay $\left(1^{\circ}-2^{\circ} \mathrm{W}, 46^{\circ}-47^{\circ} \mathrm{N}\right)$, along the French Atlantic coast, is one of these invaded ecosystems. In this site of extensive aquaculture, the oyster $C$. gigas is cultivated in plastic bags set on oyster racks as described by (Korringa, 1976). In the last decade, massive natural recruitment has been observed in this bay (Haure, unpubl. data), where the C. gigas oyster was absent thirty years ago (Gruet, 1971). This coastal ecosystem is now colonized by this invasive species (Gruet et al., 2003), while the growth performance of cultivated $C$. gigas has constantly decreased since 1994 (REMORA, 2006). Consequently, the assessment of the wild oyster stock (i.e. C. gigas not bred by oystermen) in this ecosystem has become a priority for oyster farmers and regional authorities. In this context, it was essential to identify the various types of substrate colonized by wild oysters, from natural beds occurring in rocky areas to abandoned racks of cultivated areas. The wild oyster stock was then estimated using a suitable sampling strategy based on coastal orthophotographs and its size compared to that of farmed oysters. Finally, the ecological and economic implications of the wild oyster colonization of an oyster farming site were conceptualized. 


\section{Methods}

Bourgneuf Bay, south of the Loire estuary $\left(1^{\circ}-2^{\circ} \mathrm{W}, 46^{\circ}-47^{\circ} \mathrm{N}\right.$; Figure 1$)$, is a site of extensive aquaculture of the oyster Crassostrea gigas (Thunberg), ranking sixth in France with a production of 8,600 metric tons on 1,000 hectares of beds in 2001 (Agreste, 2003). The $340 \mathrm{~km}^{2}$ of this bay are delimited in the south-west by the Isle of Noirmoutier, and in the north and south-east by the mainland. Bourgneuf Bay is connected with the ocean in the north-west by an opening of $12 \mathrm{~km}$ and in the south by a channel of 800 meters. A rocky line divides the bay and its intertidal area of 100 $\mathrm{km}^{2}$ into two parts with mud in the north and sandy mud in the south. Our study, carried out in October 2002, concerns only this northern part, which was chosen by the regional council of Pays de la Loire as a test area in order to reorganize oysterfarming structures in the whole bay. The foreshore of the northern part of Bourgneuf Bay can be divided into rocky areas and intertidal mudflats on which oyster-farming beds are located. Among the rocky areas, two types can be distinguished: rocky shores in the concession areas which are accessible only to oyster farmers, and rocky beds outside the concession areas which are accessible to everyone for shellfish gathering. A distinction can also be applied to oyster-farming beds according to their accessibility. Beds high on the foreshore can be reached on foot during low tide whereas beds low on the foreshore are situated on mudflats that are inaccessible on foot and can only be reached by boat.

\subsection{Typology of the zones colonized by wild oysters}

Two types of colonized zones were distinguished: (a) the natural beds (Fig. 1, 2A) and (b) the concession areas with the oyster-farming racks (Fig. 2D, E). The plastic bags containing the farmed oysters are set on these racks $(3 \mathrm{~m} \times 1 \mathrm{~m}), 70 \mathrm{~cm}$ from the bottom. Among the oyster-farming racks, three types were distinguished according to their condition:

- currently exploited racks; the racks are in good condition and characterized by the possible presence of oysters at their base or on the tray (Fig. 2D).

- unused racks; these structures are also in good condition but are partially to heavily colonized by wild oysters (Fig. 2E).

- abandoned racks; the structures are silted up, partially or completely destroyed, and heavily colonized by wild oysters (Fig. 2F).

With regard to the unused and abandoned racks, these strata were not present in the oyster-farming beds low on the foreshore. Four oyster-farming racks were therefore defined:

- exploited racks low on the foreshore (= low exploited racks)

- exploited, unused and abandoned racks high on the foreshore (= high exploited racks, high unused racks, and high abandoned racks).

In concession areas, two other structures were taken into account:

- old beds in the form of slate catchment basins (Fig. 2B),

- low retaining walls used in former fisheries (Fig. 2C).

These "other structures" were treated in the same way as natural beds, because of their quite similar typology, and in opposition to oyster-farming racks.

\subsection{Estimation of the wild oyster stock}

The sampling strategy was based on the implementation of stratified random sampling (Krebs, 1989). The first step consisted in determining the strata to be sampled, using the typology proposed above (§ 2.1.). Once these strata were defined, their areas were estimated by using the Geographical Information System 
(GIS) software MapInfo® to analyze Ortholittorale $2000 \AA$ [coastal orthophotographs (scale 1:10000) made available free of charge to public institutions by the French Interdepartmental Committee for National and Regional Development (CIADT)]. Natural beds and other structures areas were delimited using polygons (Fig. 1). The total area of the studied strata was the sum of each polygonal area. Using the same orthophotographs, sets of oyster-farming racks were classified into the types recognized earlier (exploited, unused or abandoned) and delimited using polygons (Fig. 3).

The estimate of the total average biomass of natural beds or other structures was defined by the product of the surface occupied by the strata in $\mathrm{m}^{2}$ as previously defined and the average oyster biomass per $\mathrm{m}^{2}$. Biomass per $\mathrm{m}^{2}$ was estimated by determining a number of sampling points proportional to the bed area (Fig. 4). For the slate catchment basins, the sampling effort was increased because of the high heterogeneity of the strata observed during field investigations. The retainment walls strata presented an high homogeneity ; the sampling effort was reduced. For each point, oysters contained in a $0.25 \mathrm{~m}^{2}$ quadrat were collected (in September 2002) and their total wet weight determined using a mechanical balance. The measured biomass was then brought back to $\mathrm{m}^{2}$.

The estimate of the total average biomass of concession area (racks) strata was defined by the product of the rack length in the strata in linear meters and the average oyster biomass per linear meter. Therefore, the polygon areas obtained using the MapInfo ${ }^{\circledR}$ GIS software were converted into linear meters of oyster rack. For the two oyster-farming beds (high and low on the foreshore), a random sampling was performed for the three types of rack. For each sampling point (the number of which was proportional to strata area, Fig. 5), wild oysters were collected (in September 2002) over the entire width of the rack and for a length of $0.5 \mathrm{~m}$. Analysis of orthophotographs have been supported by one week of ground-truthing. Checks carried out during biomass sampling showed a total adequacy between the state of the racks determined using the orthophotographs and that sampled in situ.

\subsection{Statistical analysis}

Sigmastat 3.1@ software was used for all statistical computing.

Prior to each analysis, assumptions of normality were tested with KolmogorovSmirnov tests. Mean oyster biomass between strata were compared using one-way analysis of variance (ANOVA), followed by SNK a posteriori tests.

\subsection{Analysis of seawater temperature in Bougneuf Bay since 1970}

Daily seawater temperatures (SWT) in Bourgneuf Bay were calculated between January 1970 and December 2005 using the following regression (Haure and Baud, 1995): SWT $=0.8703 \times$ Air Temperature $+0.036 \times$ Tidal coefficient -0.0969 Daily air temperatures were obtained from Météo France database (Noirmoutier Station, $2^{\circ} 15^{\prime} 24^{\prime \prime} \mathrm{W}, 47^{\circ} 00^{\prime} 18^{\prime \prime} \mathrm{N}$ ) and tidal coefficients using the Marées dans le monde 2.02@ software. 


\section{Results}

The main types of zone colonized by wild oysters in Bourgneuf Bay appear in the example of analysis by SIG MapInfo ${ }^{\circledR}$ software of the coastal orthophotograph (Fig. 3). This area is characterized by the heterogeneity of substrates colonized by wild oysters. In addition to the three types of oyster rack and to the rocks, old slate catchment basins and low retaining walls of former fisheries are also present (Fig. 2).

\subsection{Natural beds}

For natural beds on rocks and other structures, biomasses of wild oysters were significantly different between the strata (Fig. 4; ANOVA, $P<0.05$ ) and the highest ones were measured on former fisheries walls $\left(43.1 \mathrm{~kg} \cdot \mathrm{m}^{-2}\right)$. Although the total wall area involved was considerably less than that of the accessible rocks (4.2 ha vs. 73.2 ha), the total biomass for this stratum represented 1,811 tons i.e. nearly half of the total biomass of wild oysters on rocks (4,560 tons; Table 1$)$. It is also noteworthy that the distribution of the mean oyster biomass was variable among these strata: from homogeneous on former fisheries walls (Fig. 2C) with a standard deviation of 2.4 $\mathrm{kg} \cdot \mathrm{m}^{-2}(\mathrm{n}=4)$ to heterogeneous in old slate catchment basins (Fig. 2B) with a standard deviation of $12.4 \mathrm{~kg} \cdot \mathrm{m}^{-2}(\mathrm{n}=21)$. Moreover, there was a wide variability in the average oyster biomasses between rocky areas. The value obtained for inaccessible rocks (22.2 kg.m ${ }^{-2}$; Fig. 4) was almost five times greater than that for accessible rocks $\left(4.8 \mathrm{~kg} \cdot \mathrm{m}^{-2}\right)$.

\subsection{Concessions areas}

In concession areas, mean biomass of wild oysters was significantly different between the strata (ANOVA, $\mathrm{P}<0.05$ ) and the highest values measured on racks were for low exploited racks (10.5 kg per linear meter of rack; Fig. 5) and high unused racks $\left(17.1 \mathrm{~kg} \cdot \mathrm{m}^{-1}\right)$. It is also noteworthy that the distribution of the average oyster biomasses was very heterogeneous on the oyster racks (standard deviation $\geq$ mean).

Stratified random sampling provided an estimation of total biomass in concessions areas of 1,796 tons (Table 1 ).

\section{Discussion}

\subsection{Description of the wild oyster colonization}

The wild stock of $C$. gigas in the northern part of Bourgneuf Bay is estimated at 8,419 tons. These bivalves have colonized all the strata from oyster racks to slate catchment basins.

Eighty-six percent of this stock consists of wild oysters in natural beds and on other structures. Among these structures, former fisheries walls, which represent only $4 \%$ of the total area but account for nearly $30 \%$ of the total biomass (Table I), would appear to be a priority target for restructuring operations (e.g. cleaning of retainment walls, destruction of abandoned racks). It is also noteworthy that mean biomasses on inaccessible rocks were almost five times greater than those on accessible rocks (Fig. 4). This difference is probably the consequence of "human predation", by fishing on foot, of the wild oyster stocks on the accessible rocks. In the same way, the differences observed between the mean biomasses of low and high exploited racks may be explained by farming practices (Fig. 5). Indeed, farmed oyster beds low on the foreshore are accessible less often (low tides are shorter) than the others. Consequently, oyster farmers can spend less time on the upkeep of their racks, removing the wild oyster spat. The highest biomasses measured on high unused 
racks (Fig. 4) may result from the absence of oyster bags on these racks. This absence increases the space available on racks to the catchment of wild oyster spat. On the other hand, high abandoned racks are often heavily silted offering a reduced support to wild oyster spat, which may explain their low and heterogeneous biomasses of wild oysters. Finally, field observations revealed that the oyster farmers' upkeep activities are probably responsible for the variability of the average oyster biomasses on the unused and low and high exploited racks. Oyster racks that have just been cleaned no longer present wild oysters whereas those not cleaned are partially to heavily colonized.

Moreover, the 8,419 tons of wild oysters represents a tonnage 2.4 times greater than that of their conspecifics farmed in the northern part of Bourgneuf Bay (Table 1). These stocks can also be compared with the 180 tons of cultivated mussels (there are no natural mussel beds in this area) and the 1000 tons of slipper limpets (Crepidula fornicata) of the intertidal zone in this area. Thus it is clear that the wild oyster stock represents the greatest biomass of trophic competitors for the farmed oyster stock in this part of Bourgneuf Bay.

The estimated biomasses of wild oysters in concession areas represent only 1,796 tons, but the mean biomas of wild oysters at the base of racks can reach up to 55 $\mathrm{kg} \cdot \mathrm{m}^{-1}$ relative to mean farmed oyster biomasses of $20 \mathrm{~kg} \cdot \mathrm{m}^{-1}$. Thus, locally trophic competition by wild oysters could be accentuated.

Moreover, it is now well established that $C$. gigas presents a high phenotypic flexibility in response to changes in the environment (Barillé et al., 2000; Honkoop et al., 2003). Consequently, wild oysters that have developed in situ are probably better adapted to the environmental conditions than farmed oysters that have been transplanted from spat production sites and that certainly undergo a stress related to culture setting. Indeed, at least once a month, oyster bags are turned over and beaten with a stick to eliminate the epibionts (macroalgae, barnacles). Moreover, once a year these oyster bags are plunged into boiling water to destroy the oyster spat.

The differences in feeding physiology induced by the phenotypic flexibility or the stress of farming would accentuate the trophic competition exerted by wild oysters over their conspecifics and should be measured in further studies. It is obvious that the wild oyster stock should be taken into account to find a better adequacy between the levels of cupped oyster biomass and the trophic capacity of the ecosystem in which they are cultivated.

\subsection{Bourgneuf Bay warming}

An ecological and economic scheme of wild oyster colonization in relation to global warming in Bourgneuf Bay is proposed (Fig. 6). Energy contained in food is used by cultivated oysters both in growth to produce soma and in reproduction to produce gonads (Barillé et al., 1997). Oyster farmers look for this somatic production (= fattening) for their sales. At this level, a temperature threshold intervenes. In fact, spawning of mature $C$. gigas requires a seawater temperature above $18{ }^{\circ} \mathrm{C}$ (Mann, 1979). If this threshold is not reached, gonad can be transformed into reserve tissues (Méléder et al., 2001). This phenomenon, increasing the fattening, has a positive impact for oyster farmers whereas spawning when the temperature is above $18{ }^{\circ} \mathrm{C}$, represents a loss in production.

When the seawater temperature allows $C$. gigas to spawn, larval survival requires sustained temperatures of $22{ }^{\circ} \mathrm{C}$ for at least 2 weeks, before the pelagic larvae 
complete metamorphosis into spat [i.e. sessile animals] (Seno et al., 1926; Arakawa, 1990; Shatkin et al., 1997; Hofmann et al., 2004). This water temperature requirement may be the reason that no successful $C$. gigas larval recruitment was reported in Bourgneuf Bay during the twenty years following its introduction in the 1970's. However, the number of days with a seawater temperature above the $22{ }^{\circ} \mathrm{C}$ threshold has increased during the last decade in Bourgneuf Bay (Fig. 7). Between 1995 and 2005, five years presented sustained temperature of $22^{\circ} \mathrm{C}$ during at least 2 weeks, whereas these temperature conditions were encountered only two years between 1970 and 1994. Moreover, with a residence time of water masses in Bourgneuf Bay superior to 2 months (Lazure, 1992), C. gigas larvae may be retained until their spatfall. Field observations reinforce this hypothesis of warming effect: since 1995 a massive and regular spatfall of $C$. gigas has been observed in Bourgneuf Bay (Haure, unpubl. data), allowing the settlement of a wild stock of this species.

The resulting trophic competition between wild C. gigas and their cultivated conspecifics may contribute to explain the decrease in growth performance of cultivated oysters observed since 1994 (REMORA, 2006). Indeed, changes in other parameters which may explain this decline such as salinity, water quality or prevalence of parasites were not observed (REPHY, 2006). The loss in production represents a loss of earnings for oyster farmers but autochthonous recruitment also implies an increase in the upkeep costs of concession areas. Indeed, oyster farmers spend a lot of time cleaning oyster-farming racks and trays colonized by the spat. Moreover, tray treatment by scalding (warming) often leads to farmed oyster mortality.

The problem of the oyster industry in Bourgneuf Bay is a good illustration that the chance of a successful invasion (i.e. the establishment of a reproducing and persisting population) of a temperate coastal ecosystem by a less northern species, with its share of economic and ecological consequences, is increased by global warming.

\subsection{Impact on native biota}

The size of the wild oyster stock in the northern part of Bourgneuf Bay raises another question: might these invaders affect the native biota? Negative impacts of the introduced C. gigas on native biota are quite well documented. In Australia, the ubiquitous $C$. gigas began to dominate some major seed catching areas of the native Sydney rock oyster Saccostrea commercialis only 3 decades after its introduction (Chew, 1990). The threat was such that, to protect this commercialized species, the eradication of the Pacific oyster was undertaken. In New-Zealand, the native Rock oyster S. glomerata was outcompeted by the introduced C. gigas within a decade of its arrival (Dinamani, 1991). In Willapa Bay (Washington State, USA), C. gigas is probably responsible for the limitation of the native oyster Ostrea conchaphila population, through modifications of its habitat (Ruesink et al., 2005). In Argentina and in the Wadden sea, C. gigas recruits on beds of native mussels that may be overgrown (Reise, 1998; Orensanz et al., 2002). C. gigas may also outcompete for spatial niche the native barnacles inhabiting these mussel beds (Reise, 1998). In the Oosterschelde estuary (Netherlands) C. gigas was observed to replace former soft bottom communities by a hard substrate community (Troost et al., 2003).

Development of $C$. gigas reefs may also affect higher trophic levels, enhancing food availability for bivalve predators or increasing shelter availability for epifaunal species 
(Richardson et al., 1993; Yamada et al., 1993; Escapa et al., 2004; Grabowski and Powers, 2004).

Until recent years, the sessile fauna of rocky shores in the northern part of Bourgneuf Bay was dominated by different species of barnacles while the mussel Mytilus edulis (Gruet, 1971) and C. gigas had seldom been observed. Recent observations have shown that $C$. gigas has become dominant in some of these rocky areas (Gruet et al., 2001) where mussels and barnacles have gradually disappeared. Moreover, during our sampling, wild oysters were observed in rocky areas usually colonized by the honeycomb worm Sabellaria alveolata (Gruet, 1971, 1972, 1982). This polychaete constructs reefs protected by the European Community Habitats Directive (Council Directive 92/43/EEC on the Conservation of Natural Habitats and of Wild Fauna and Flora, 1992). Wild C. gigas is therefore a potential competitor of this suspension-feeding species not only at the trophic level but also for the space available on rocky shores (Fig. 6). Consequently, the role of the Pacific oyster wild stock in the biota of Bourgneuf Bay is not negligible and should be taken into account in conservation management in this marine environment.

This preliminary study concerned only the northern part of Bourgneuf Bay and should be extended to the whole bay. However, for the future of this bay, it already seems essential from both an economic (oyster farming) and an ecological standpoint (native biota) to take decisions in order to limit the trophic and spatial competition exerted by wild $C$. gigas. With regard to the results obtained in this study, oyster farmers and regional authorities have taken measures to reorganize oyster-farming structures and to destroy wild oyster stocks in concession areas. Mass harvesting of the substrate attached oysters was not considered. However, in rocky areas (at least in accessible ones) wild C. gigas populations could be limited by increasing shellfish gathering quotas.

In conclusion, although the introductions of bivalve mollusks have proved to be beneficial, augmenting a depressed or dying fishery industry, these introductions generate side effects that have an impact not only on the native biota of ecosystems but also on the aquaculture industry itself. 


\section{Acknowledgments}

We thank P. Decottignies and P. Rosa for their assistance in field. This research was carried out with a financial support from the Région des Pays de la Loire and the Syndicat MIxte pour le Développement de l'Aquaculture et de la Pêche en Pays de Loire.

\section{References}

Agreste, 2003. Recensement de la conchyliculture 2002. Ministère de l'agriculture, de l'alimentation, de la pêche et des affaires rurales, pp. 4.

Arakawa, K.Y., 1990. Natural spat collecting in the Pacific oyster Crassostrea gigas (Thunberg). Marine Behaviour and Physiology 17, 95-128.

Barillé-Boyer, A.-L., Haure, J. and Baud, J.-P., 1997. L'ostréiculture en Baie de Bourgneuf, relation entre la croissance des huîtres Crassostrea gigas et le milieu naturel. Synthèse de 1986 à 1995. IFREMER, pp. 173.

Barillé, L. and Barillé, A.-L., 2003. Estimation du stock de crépidules dans la zone intertidale de la baie de Bourgneuf. Rapport Université de Nantes pour la section régionale conchylicole des Pays de la Loire.

Barillé, L., Héral, M. and Barillé-Boyer, A.-L., 1997. Modélisation de l'écophysiologie de l'huître Crassostrea gigas dans un environnement estuarien. Aquat. Living Resour. 10, 31-48.

Barillé, L., Haure, J., Cognie, B. and Leroy, A., 2000. Variations in pallial organs and eulatero-frontal cirri in response to high particulate matter concentrations in the oyster Crassostrea gigas. Can. J. Fish. Aquat. Sci. 57, 837-843.

Carlton, J.T., 1987. Patterns of transoceanic marine biological invasions in the pacific ocean. Bull. Mar. Sci. 41, 452-465.

Carlton, J.T. and Geller, J.B., 1993. Ecological roulette: the global transport of non indigenous marine organisms. Science 261, 78-82.

Chew, K.C., 1990. Global bivalve shellfish introductions. World Aquaculture 21, 9-22.

Dinamani, P., 1991. Introduced Pacific oysters in New Zealand. In: Greer, M.C., Leffler, J.C. (Eds.), The Ecology of Crassostrea gigas in Australia, New Zealand, France and Washington State, Maryland Sea Grant, College Park, Maryland, pp. 912.

Escapa, M., Isacch, J.P., Daleo, P., Alberti, J., Iribarne, O., Borges, M., Dos Santos, E.P., Gagliardini, D.A. and Lasta, M., 2004. The distribution and ecological effects of the introduced pacific oyster Crassostrea gigas (Thunberg, 1793) in Northern Patagonia. Journal of Shellfish Research 23, 765-772.

Grabowski, J.H. and Powers, S.P., 2004. Habitat complexity mitigates trophic transfer on oyster reefs. Marine Ecology Progress Series 277, 291-295.

Grizel, L., 1996. Quelques exemples d'introductions et de transferts de mollusques. Revue scientifique et technique de l'Office international des épizooties 15, 401-408. Gruet, Y., 1971. Morphologie, croissance et faune associée des récifs de Sabellaria alveolata (Linné) de la Bernerie-en-Retz (Loire-Atlantique). Téthys 3, 321-380. Gruet, Y., 1972. Aspects morphologiques et dynamiques de constructions de I'Annélide Polychète Sabellaria alveolata (Linné). Revue des Travaux de l'Institut des Pêches maritimes 36, 131-161.

Gruet, Y., 1982. Recherches sur l'écologie des "récifs" d'Hermelles édifiés par l'Annélide Polychète Sabellaria alveolata (Linné). Thesis, University of Nantes, 238 pp.

Gruet, Y., Barillé-Boyer, A.-L., Barillé, L., Pérusson, O., Pineau, M., Le Neuthiec, R., Baudet, J. and Rincé, Y., 2001. Impact écologique de la marée noire de l'Erika sur la 
faune marine d'invertébrés benthiques de l'estran de Loire-Atlantique et de Vendée. Direction Régionale de l'Environnement des Pays de la Loire, Préfecture de Région, Nantes, pp. 140.

Gruet, Y., Barillé-Boyer, A.-L., Barillé, L., Pérusson, O., Pineau, M., Le Neuthiec, R., Baudet, J. and Rincé, Y., 2003. Impact écologique de la marée noire de l'Erika sur la faune marine d'invertébrés benthiques de l'estran de Loire-Atlantique et de Vendée. Haure, J. and Baud, J.-P., 1995. Approche de la capacité trophique dans un bassin ostréicole (baie de Bourgneuf), 106 pp.

Haure, J., Martin, J.-L., Y., Dupuy, B., Nourry, M., Palavadeau, H., Papin, M., Pénisson, C., Le Moine, O., Geairon, P. and Razet, D., 2003. Estimation des stocks d'huîtres en élevage dans la baie de Bourgneuf en 2002. IFREMER, pp. 21.

Hayward, P.J. and Ryland, J.S., 1995. Handbook of the Marine Fauna of North-West Europe. Oxford University Press, 800 pp.

Hofmann, E.E., Powell, E.N., Bochenek, E.A. and Klinck, J.A., 2004. A modelling study of the influence of environment and food supply on survival of Crassostrea gigas larvae. Ices Journal of Marine Science 61, 596-616.

Honkoop, P.J.C., Bayne, B.L. and Drent, J., 2003. Flexibility of size of gills and palps in the Sydney rock oyster Saccostrea glomerata (Gould, 1850) and the Pacific oyster Crassostrea gigas (Thunberg, 1793). J. Exp. Mar. Biol. Ecol. 282, 113-133.

Kluijver, M.J. and Leewis, R.J., 1994. Changes in the sublittoral hard substrate communities in the Oosterschelde estuary (SW Netherlands), caused by changes in the environnemental parameters. Hydrobiologia 282/283, 265-280.

Korringa, P., 1976. Farming the cupped oysters of the genus Crassostrea. Elsevier, Amsterdam, 224 pp.

Krebs, C.J., 1989. Ecological Methodology. Harper-Row, New-York, 654 pp. Lazure, P., 1992. Etude de l'hydrodynamisme de la baie de Bourgneuf. Rapport pour la préfecture de la région des Pays de la Loire (SESGAR). Rapport IFREMER DEL/92-24, pp. 20.

Le Borgne, M., Gras, M.P., Comps, M., Carruesco, G. and Razet, D., 1973. Observations sur la reproduction des huîtres dans la Seudre (Bassin de MarennesOléron) en 1972, 5 pp.

Mann, R., 1979. Some biochemical and physiological aspect of growth and gametogenesis in Crassostrea gigas and Ostrea edulis grown at sustained elevated temperatures. Journal of marine biological association of United Kingdom 59, 95-110. Méléder, V., Barillé-Boyer, A.L., Baud, J.P., Barillé, L., Cognie, B. and Rosa, P., 2001. Modelling oyster Crassostrea gigas fattening with the diatom Skeletonema costatum. Aquatic Living Resources 14, 49-64.

Naylor, R.L., Williams, S.L. and Strong, D.R., 2001. Aquaculture - A gateway for exotic species. Science 294, 1655-1656.

Orensanz, J.M., Schwindt, E., Pastorino, G., Bortolus, A., Casas, G., Darrigran, G., Elias, R., Lopez Gappa, J.J., Obenat, S., Pascual, M., Penchaszadeh, P., Piriz, M.L., Scarabino, F., Spivak, E.D. and Vallarino, E.A., 2002. No longer the pristine confines of the the world ocean: a survey of exotic marine species in the southwestern Atlantic. Biological Invasions 4, 115-143.

Reise, K., 1998. Pacific oysters invade mussel beds in the European Wadden Sea. Senckenbergiana maritima 28, 167-175.

REMORA, 2006. Réseau Mollusques des Rendements Aquacoles : annual reports (1993-2004). IFREMER. http://www.ifremer.fr/remora/

REPHY, 2006. Réseau de surveillance du phytoplancton et des phycotoxines : annual reports (1995-2006). IFREMER. http://www.ifremer.fr/envlit/index.html 
Richardson, C.A., Seed, R., Alroumaihi, E.M.H. and McDonald, L., 1993. Distribution, shell growth and predation of the New Zealand oyster, Tiostrea (= Ostrea) lutaria Hutton, in the Menai Strait, North Wales. Journal of Shellfish Research 12, 207-214. Ruesink, J.L., Lenihan, H.S., Trimble, A.C., Heiman, K.W., Micheli, F., Byers, J.E. and Kay, M.C., 2005. Introduction of non-native oysters: ecosystem effects and restoration implications. Annual Review of Ecology, Evolution and Systematics 36, 643-689.

Seno, H., Hori, J. and Kusakabe, D., 1926. Effects of temperature and salinity on the development of the eggs of the common Japanese oyster, Ostrea gigas Thunberg. Journal of the Imperial Fisheries Institutes 22, 41-47.

Shatkin, G., Shumway, S.E. and Hawes, R., 1997. Considerations regarding the possible introduction of the Pacific oyster (Crassostrea gigas) to the Gulf of Maine: a review of global experience. J. Shellfish Res. 16, 463-477.

Troost, K., Wolff, W.J., Kamermans, P., Stamhuis, E.J., Smaal, A. and Herman, P., 2003. The invasion of an introduced species, the Japanese cupped oyster Crassostrea gigas, in Dutch estuarine ecosystems. Haliotis 33, 231.

Yamada, S.B., Metcalf, H. and Baldwin, B.C., 1993. Predation by the pygmy rock crab Cancer oregonensis (Dana, 1852) inside oyster trays. Journal of Shellfish Research 12, 89-92. 
Table 1. Biomasses of wild oyster C. gigas and principal others suspension-feeders in the northern part of Bourgneuf Bay. For the typology, see Materials and Methods section, § 2.1. (1): (Haure et al., 2003); (2): (Barillé-Boyer et al., 1997); (3): (Barillé and Barillé, 2003).

\begin{tabular}{lcc} 
& $\begin{array}{c}\text { Biomass } \\
\text { (tons) }\end{array}$ & $\begin{array}{c}\text { Area } \\
\text { (ha) }\end{array}$ \\
\hline Wild oysters in natural beds & $\mathbf{6 , 6 2 3}$ & 83,3 \\
Accessible rocks & 3,619 & 73.2 \\
Non accessible rocks & 941 & 4.2 \\
Slate catchment basins & 252 & 1.7 \\
Former fisheries walls & 1,811 & 4.2 \\
\hline Wild oysters in concessions areas & $\mathbf{1 , 7 9 6}$ & 69.4 \\
\hline Farmed oysters in concession areas (1) & $\mathbf{3 , 4 2 0}$ & 69.4 \\
\hline Cultivated mussels (2) & $\mathbf{1 8 0}$ & - \\
\hline Crepidula fornicata (3) & $\mathbf{1 , 0 0 0}$ & 88
\end{tabular}


Figure 1. A: Location of Bourgneuf Bay; B: Division of the northern part of Bourgneuf Bay into geographical entities where wild oysters $C$. gigas are encountered. Rocky shores and digitalized oyster concessions were reported on the geo-referenced orthophotograph Ortholittorale $2000 \AA$.

$\square$ : accessible rocks; $\square$ : inaccessible rocks; oyster-farming beds high: $\square$ and low: on the foreshore.

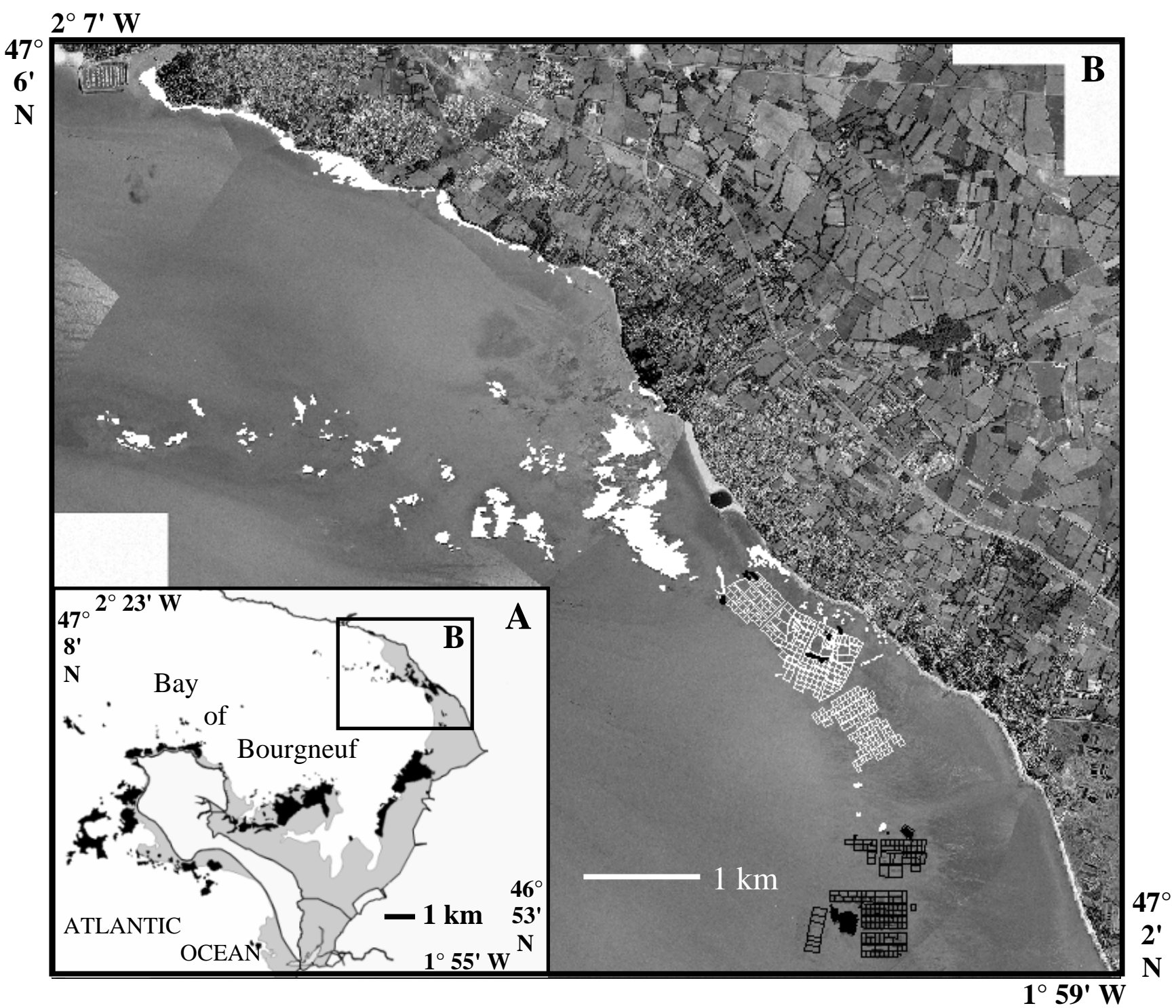


Figure 2. Typology of the sampled areas and structures colonized by wild oysters $C$. gigas in Bourgneuf Bay. A: Rocks; B: Old slate catchment basins; C: retaining walls of former fisheries; D: exploited racks; E: unused racks; F: abandoned racks.
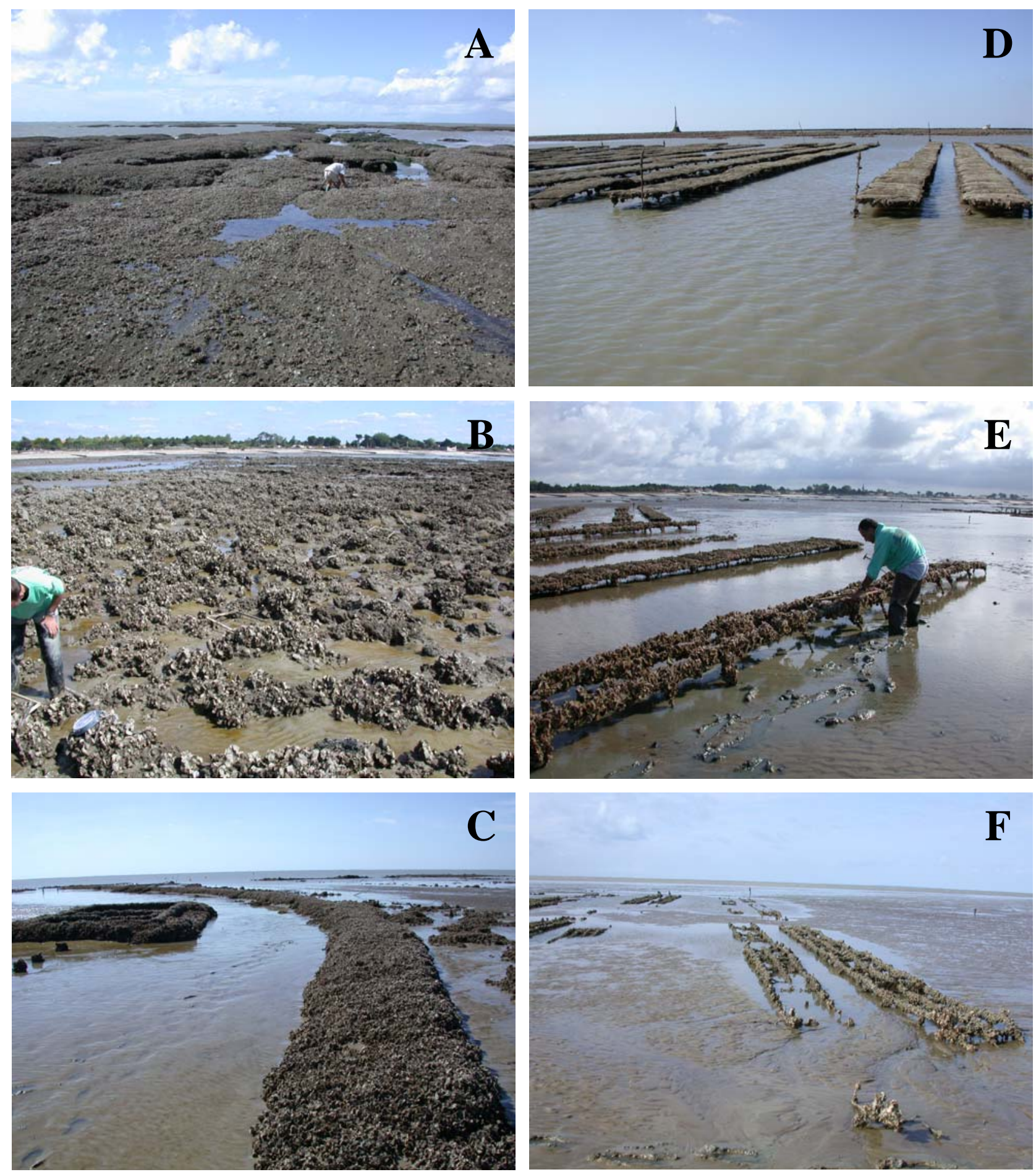
Figure 3. Analysis by GIS Maplnfo ${ }^{\circledR}$ software of a concession area high on the foreshore in the northern part of Bourgneuf Bay. For the typology, see Materials and Methods section, § 1.

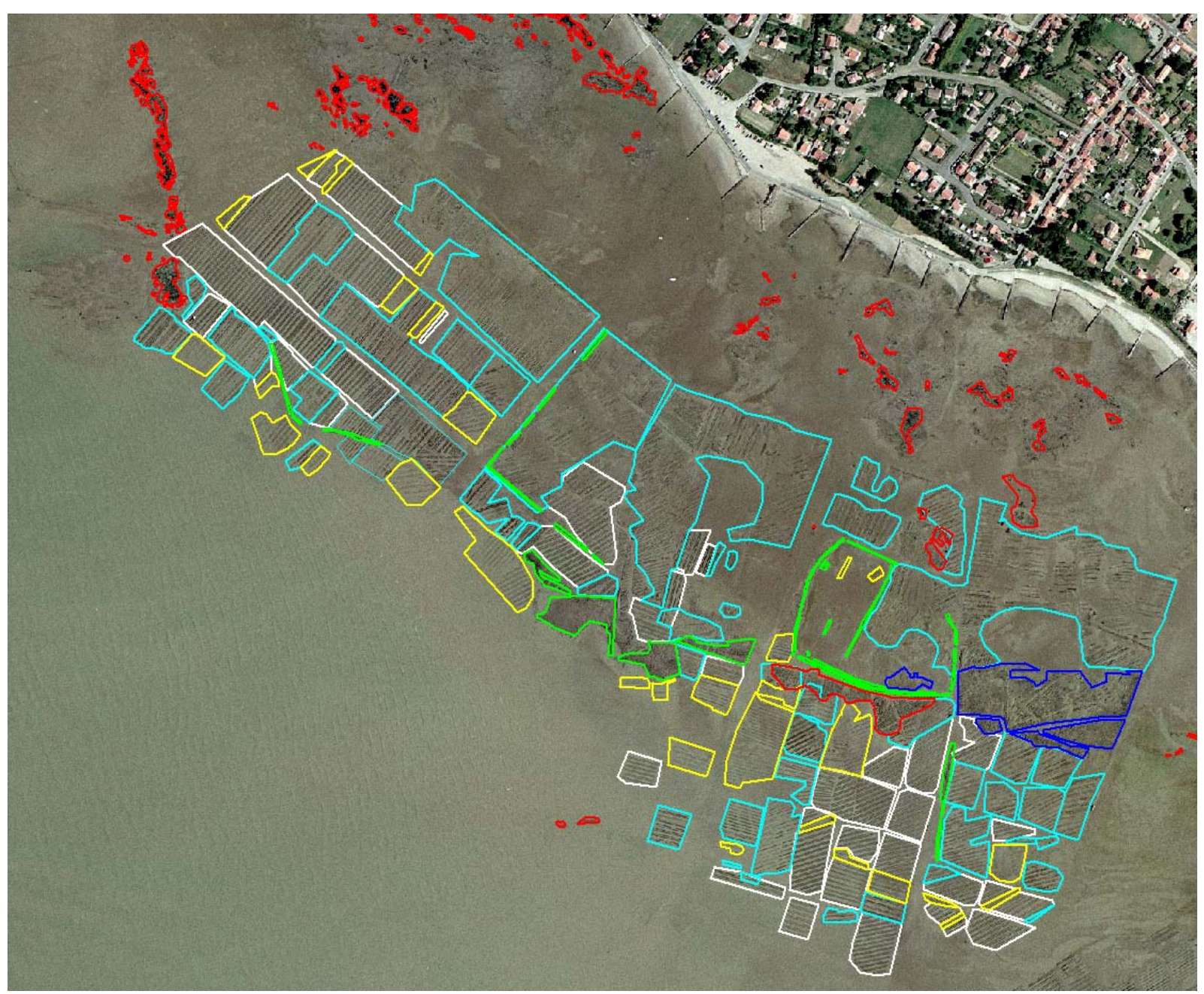


Figure 4. Mean biomass of wild oysters $C$. gigas for natural beds and other structures. For the typology, see Materials and Methods section, $\S 1$. Number of replicates are indicated inside histogram bars. Error bars indicate the upper $95 \%$ confidence limit of the mean. Bars with different lower case letters are significantly different $(P<0.05)$.

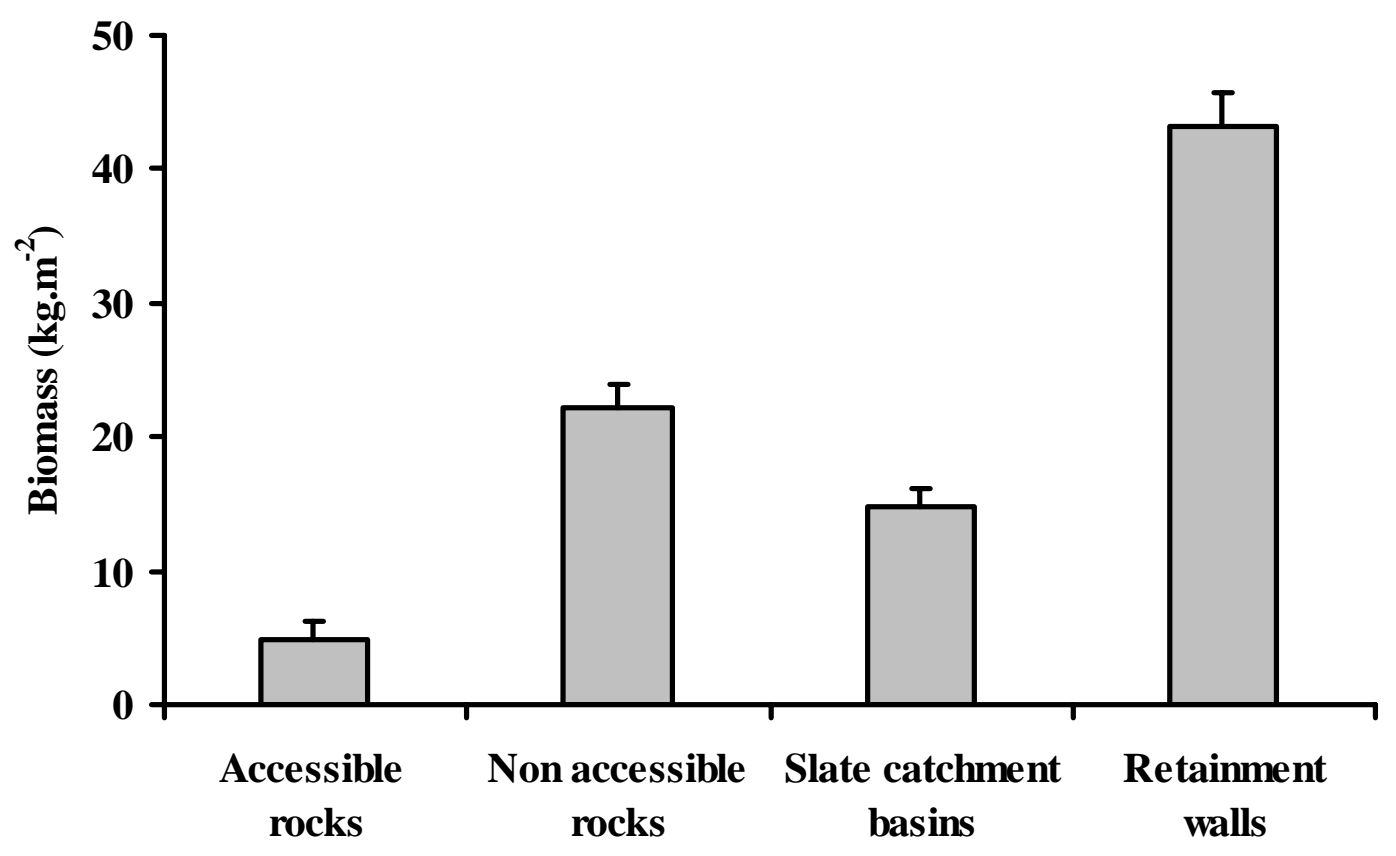


Figure 5. Mean biomass of wild oysters $C$. gigas for concession areas. For the typology, see Materials and Methods section, $\S 1$. Number of replicates are indicated inside histogram bars. Error bars indicate the upper $95 \%$ confidence limit of the mean. Bars with different lower case letters are significantly different $(P<0.05)$.

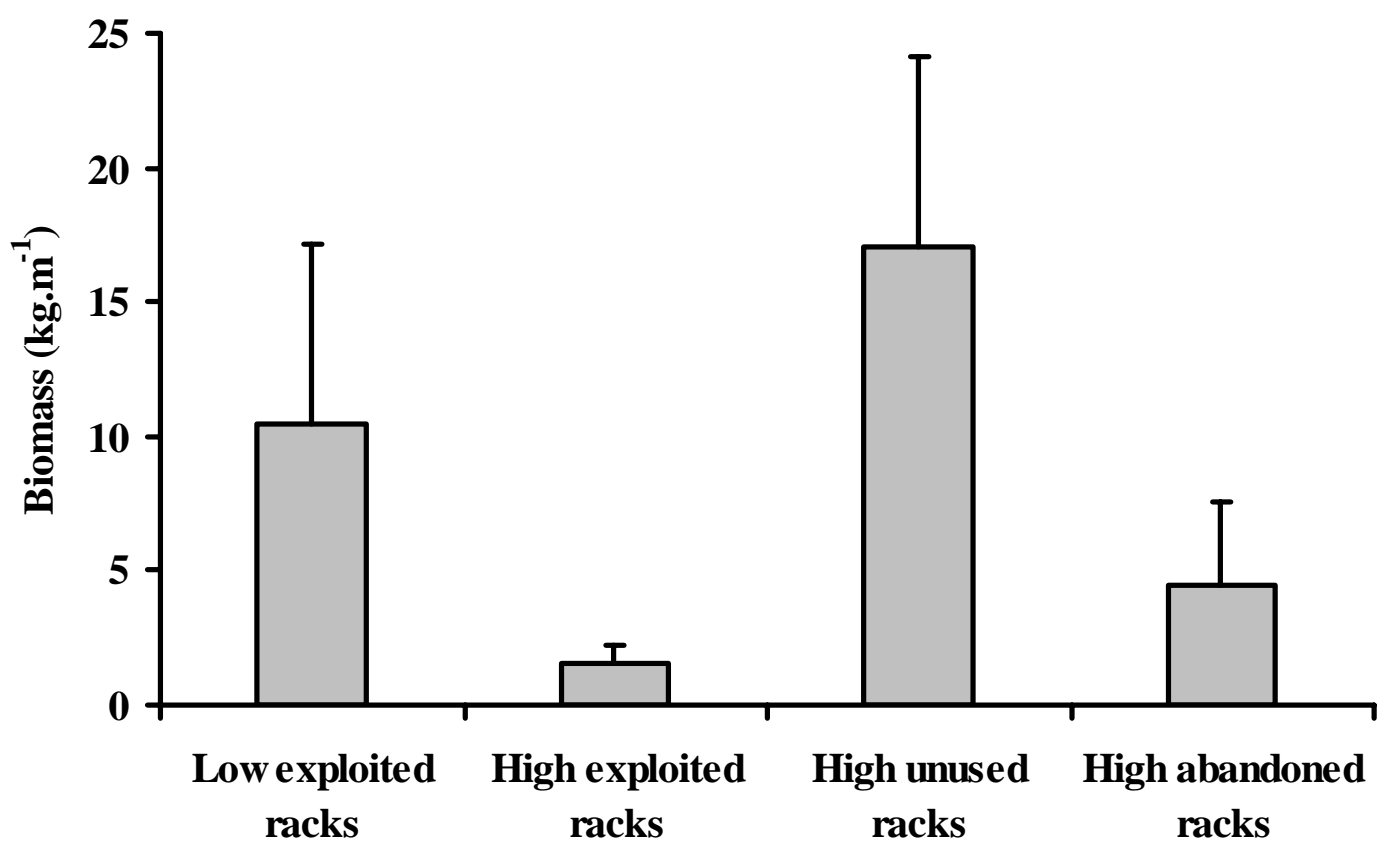


Figure 6. Ecological and economic conceptualization of the wild oyster colonization.

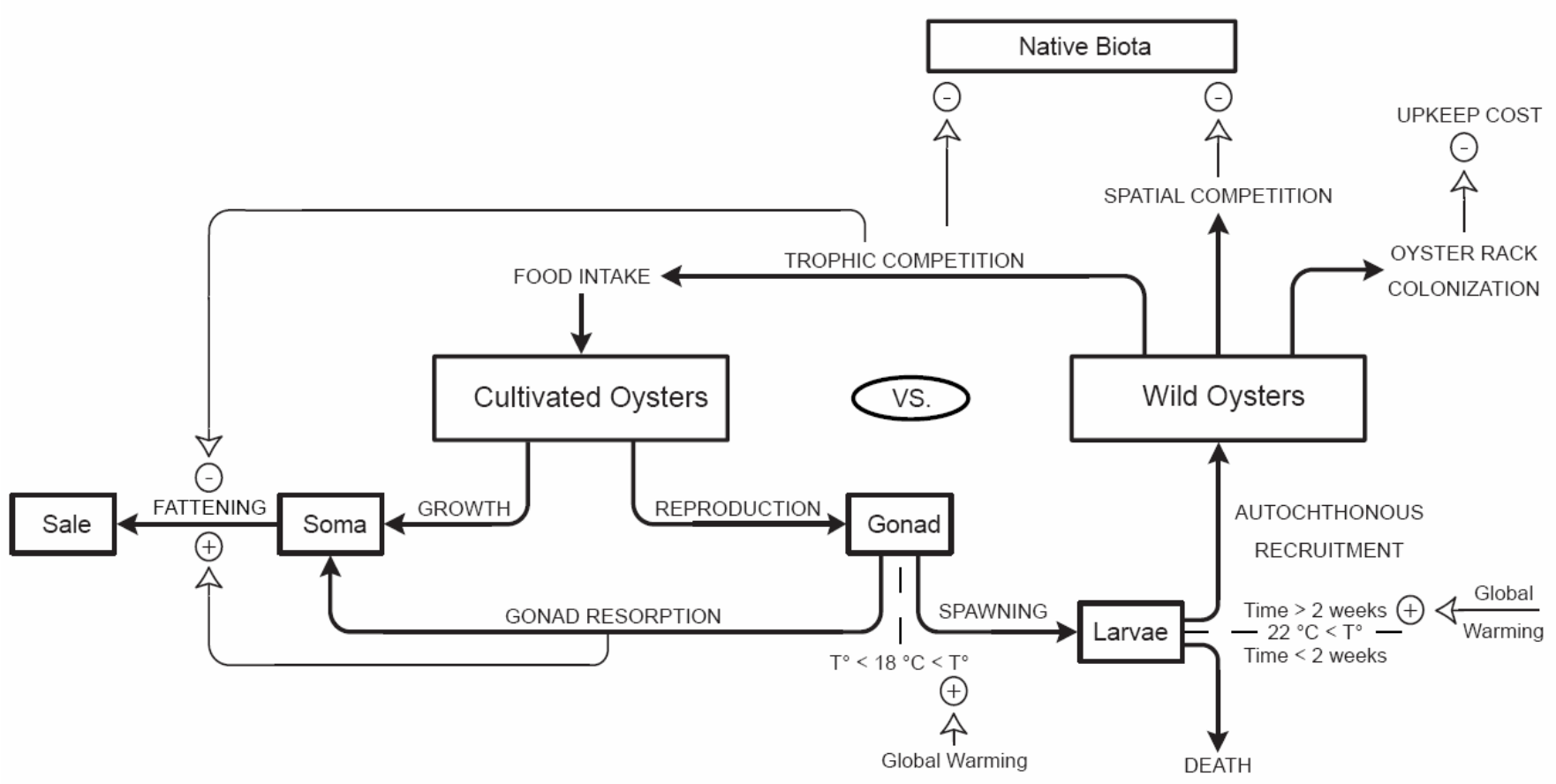


Figure 7. Number of days with seawater temperature (SWT) above $22{ }^{\circ} \mathrm{C}$ in Bourgneuf Bay since 1970.

The years with SWT above $22{ }^{\circ} \mathrm{C}$ during more than 2 weeks are indicated with an arrow.

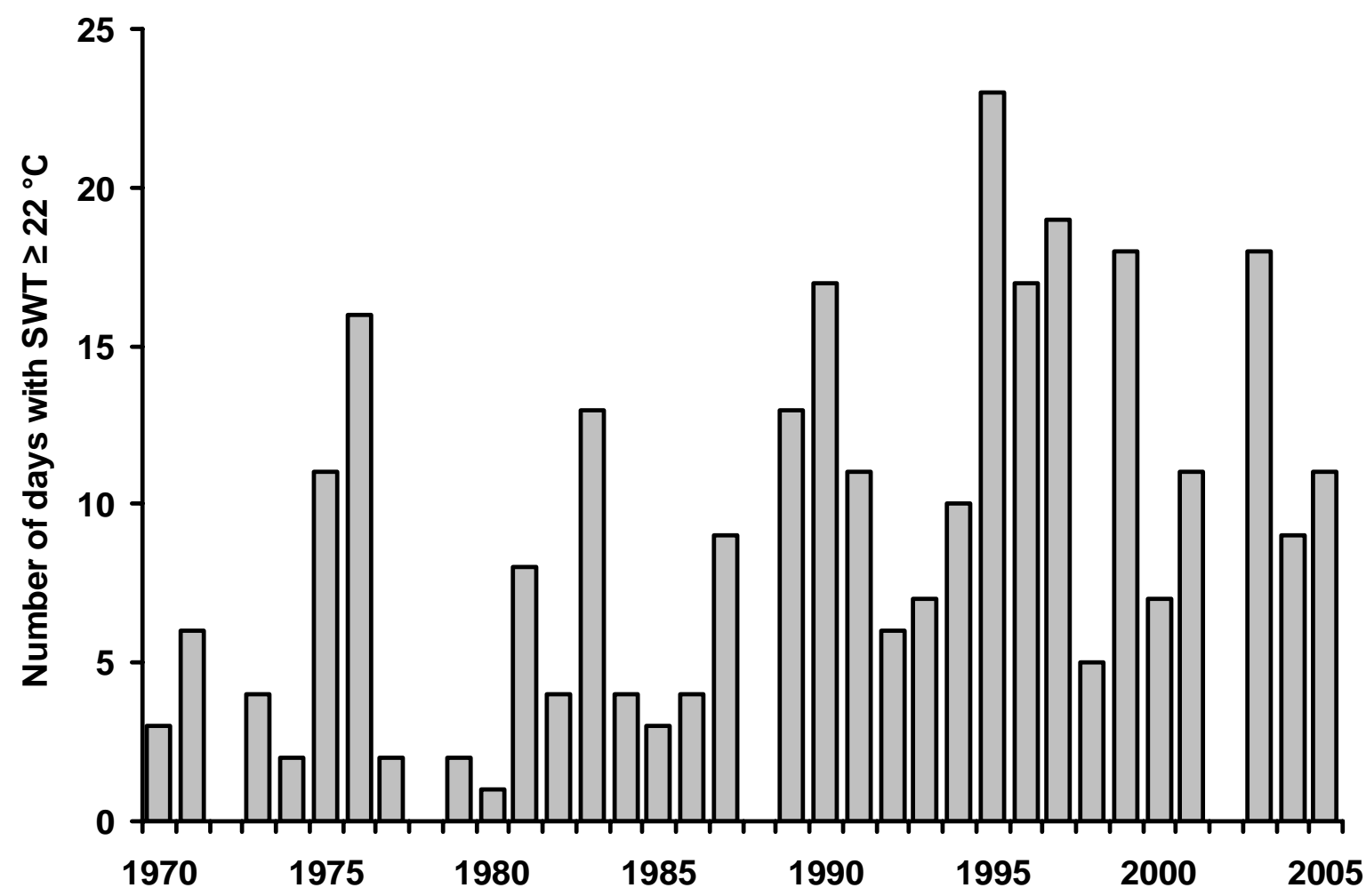

